\title{
Rubrics as a tool to coordinate assessment and progress in different design workshops of the degree in Industrial Design Engineering and Product Development
}

\author{
Marina Puyuelo ${ }^{a}$, Elisa March b, Javier Aparisi ${ }^{\mathrm{c}}$, Bélgica Pacheco-Blanco ${ }^{\mathrm{d}}$, Chele Esteve ${ }^{\mathrm{e}}$, \\ Margarita Valor ${ }^{\mathrm{f}}$ and Ernesto Julià
}

${ }^{a}$ Universitat Politècnica de València, ETSID, Valencia, Spain mapuca@ega.upv.es,

bUniversitat Politècnica de València, ETSID,, Valencia, Spain emarch@dib.upv.es,

${ }^{c}$ Universitat Politècnica de València, ETSID, Valencia, Spain jaaptor@dig.upv.es,

${ }^{\mathrm{d}}$ Universitat Politècnica de València, ETSID, Valencia, Spain blpacbla@dpi.upv.es,

${ }^{e}$ Universitat Politècnica de València, ETSID, Valencia, Spain maessen@dib.upv.es,

${ }^{\mathrm{f} U n i v e r s i t a t ~ P o l i t e ̀ c n i c a ~ d e ~ V a l e ̀ n c i a, ~ E T S I D, ~ A l c o y, ~ S p a i n ~ m v a l o r @ d i g . u p v . e s ~}$

${ }^{\mathrm{g}}$ Universitat Politècnica de València, ETSID, Alcoy, Spain erjusan@mes.upv.es

\begin{abstract}
The changes provided by the EEES constitute a challenge and an opportunity to introduce methods and improvements in technical careers. The assessment of this scenario has an important and strategic role, which requires paying more attention to the competency evaluation. This paper describes the method and the collaborative task carried out to develop the rubrics for the three-year Workshop Project in the framework of the undergraduate Bachelor's Degree in Industrial Design Engineering and Product Development. The purpose of this was to overcome challenges while assessing design projects in different workshops and by different professors. The team predicted that these rubrics would have a significant effect on the students' outcomes and their performance on various tasks. The implementation of the rubrics on the different levels is expected to sustain interesting possibilities to compare not only the results in different courses but the actual progress. The stages of the process of making these rubrics are presented in relation to the specific, general and shared competences of each of the 3 workshops. The rubrics, that will be published online, are related to the assessment of the results obtained and the competences. Rubrics may not only boost academic performance and reduce failure, but improve the quality of the projects as well.
\end{abstract}

Keywords: Design competences, rubrics, critical thinking, workshop, projectbased learning.. 
Rubrics as a tool to coordinate assessment and progress in different design workshops of the degree in Industrial Design Engineering and Product Development

\section{Introduction}

This article presents the design of rubrics agreed upon for the three courses given in the Workshop Project and the hypothesis that this assessment tool plays a fundamental role in the coordination and articulation of progress for the achievement of the expected competency levels in these workshops. In the curriculum of the degree in Industrial Design Engineering and Product Development (18 ECTS, or credits) the module of Design Speciality is divided in 6credit subjects taken in three consecutive years. At present, coordination between these subjects is complicated due to their presence in different courses, and their assignment to different departments with differing and occasionally isolated approaches given to the subject. For this reason, to improve students' learning, it has been deemed necessary to set out a strategy which would allow for proper consistency between the subject matter, the learning outcomes, and the skills acquired at the end of the studies. To this end we are working on a Teaching Innovation Project whose aim is to outline some common guidelines to articulate and promote the coordination and the role of the Workshop Project in this degree program and in the two universities that teach it: the Escuela Técnica Superior de Ingeniería del Diseño and the Escuela Politècnica Superior de Alcoy, both under the Universitat Politècnica de València (UPV).

The workshops are essentially active learning settings which, compared to traditional learning methods, have many advantages. The most noteworthy are: the increase in involvement of the students in the process; the fundamental practical component, and its focus on project based learning (PBL). Let's look at how these aspects have a bearing on the acquisition of skills characteristic of the workshop.

For example, involvement leads to the development and acquisition of skills related to putting knowledge into practice, the application of theoretical knowledge for problem solving, and, at the same time, other skills such as working in a team, looking for information, or the ability to work independently. (Biggs, 2003; Conchado, 2011).

The next characteristic of the workshops as active learning settings is that the students learn through the application of theoretical knowledge in real situations. The experience obtained through practical and/or real examples, or even through simulations of practical situations is a very relevant feature for good professional preparation and provides progressive contact with the reality of the working environment from the beginning of their studies (Schön, 1987). Likewise, presenting a context with practical meaning proves even more stimulating for the students (Gerritsen, 1999). In the workshop teaching/learning process, the students are asked to develop appropriate solutions through constructive practice, apply procedures to transform the available information and materials, and interpret the results, using the teacher's questions and supervision as an additional motivation. As De Miguel has noted, it is understood that the 
student learns in a more pertinent way through experimentation, practicing, or simply investigating the nature of everyday phenomena and activities (De Miguel et al., 2005).

In addition, the project based learning method (PBL) is the common design pedagogy at the different workshops guided by the professors. This method is appropriate for teaching and learning complex activities on the basis of "constructionism theory", where the knowledge is not transmitted from teacher to student, but actively constructed in the mind (Bin Yang, 2010). Furthermore, it is assumed that learners are more creative when they are actively engaged in doing something external like models or objects, when they can think and share with others. Design workshops have this sort of learning environment, with authentic tasks, multiple means of expression and hands-on approaches to design.

In this scenario, assessment not only has a main and strategic role to support learning and competency acquisition, but also the perception of teaching and progress from students. Therefore, assessment in higher education has an educative value as part of the learning process (Mervat and Hanan, 2015). The core of this project is the development of evaluation rubrics that act as an instrument of coordination among the different workshop subjects and also as observational supports of the design projects' results.

This article is organized in three sections. Firstly, the characteristics of the competency evaluations in the subject Design Workshop will be presented, as well as the advantages of rubrics as instruments of orientation and communication while acquiring the aforementioned competencies. The next section makes up the core of this project as it describes the process of designing the rubrics as a way of coordinating the workshop subjects, dealing with the levels of the different courses, and finally, presenting the global evaluation rubrics for each one of the workshops, followed by a brief conclusion and recommendations for the future.

\section{Assessment and competences in Design Workshops. The role of rubrics in learning design}

The instructional goal for competency development implies the acquisition of knowledge, the development of skills, and the ability to apply these resources appropriately in any situation that comes up. The innovation of this assessment is a logical consequence of the approach of instruction as the development of competencies, and thus is an essential part of the innovation of this process (Villaron, 2006).

From its beginnings, the design project has, first of all, addressed the formal and aesthetic definition of products and services. However, this configuration activity is changing to meet more complex and diversified demands that require the involvement of design in planning 
strategies, in development and innovation from a multidisciplinary perspective. (Bin Yang, 2010). This presents new challenges in the field of design in the workshop since this is already the object of practical instruction and of a contextualized evaluation in which students' achievements are considered within a practical context, in a constant state of problem solving and case studies. In this diverse context, assessment as a way to regulate learning takes on a greater importance as it makes it clear to the students what the requirements are, and thus shows them how to manage their work, adjusting it to the conditions of the specific evaluation requirements. (Rodrigo et alt, 2017) .

Innovative assessment for this ongoing PBL process varies and requires frequent updated methods. Rubrics provide clear guidelines, criteria and descriptions with a standard and a descriptive statement that illustrates how the work is to be achieved. The rubric is an assessment tool that lists the criteria for a piece of work or what counts and articulates gradations of quality for each criterion (Goodrich, 2013)

In this educational project, the rubric will allow us to itemize the specific criteria that need to be taken into account when evaluating the student, making the evaluation process easier and more transparent. Among the advantages that the use of rubrics can provide, we can highlight that they facilitate the teacher's evaluation process while increasing the coordination among the various educators in the field of design by previously defining and agreeing on what is expected of the students in the different stages of the development of a project. In addition, it reduces the feeling of ambiguity that students may have when they are evaluated, allowing the skill set to be organized on the basis of a value judgment that is established and, therefore, guarantees a fairer evaluation.

It is accepted that, despite all its problems, using rubrics is a major step forward in education (Bing Yang, 2010). Therefore, for this project of Innovative learning we decided to improve Workshop Project within the framework of the undergraduate Bachelor's Degree in Industrial Design Engineering and Product Development, by developing these rubrics.

\section{Developing rubrics in Design Workshops}

\subsection{Objectives}

The development of these rubrics has had the general objective of establishing a dialogue between the evaluating parties that encourage workshop learning in the two universities that offer the degree of Design Engineering in the UPV. 
The specific objectives to be laid out by common rubrics are:

- Having an instrument for the validation of PBL methodology in the context of teaching in different workshops.

- Increasing the vertical coordination of learning and observing the modification of the results in the different levels/courses and decreasing discrepancies.

- Providing coherence and transparency to the evaluation of the learning results in the workshops.

- Motivating the students by using the rubrics as guidelines to learning.

Once defined, the rubrics must be implemented by matching them with the corresponding learning outcomes, so that a specific guideline is provided to the faculty in order to unify assessment criteria and also for the students, regarding the requirements placed on them.

\subsection{Methods and materials}

The class time and 18 credits that make up the three Workshop Projects pursue the development of the students' projective skills. The distribution of these subjects between the $3^{\text {rd }}$ and the $7^{\text {th }}$ semester determines the individual objectives and competencies of each one of them, as well as the cross-curricular relationship and the vertical coordination in the three consecutive years.

The approach and development of the rubrics was done in the following stages:

1. First, a debate was opened between the whole project team and all the professors who are responsible for teaching the different workshops to clarify the objectives of each one and to bring together the different approaches, the relationship with other subjects, the main problems, and the characteristics of the work being carried out. The collection of results from the different workshops was specified.

2. Performance criteria and set performance levels were identified. We analysed how competencies were being approached in the different workshops, and their relationship with other competencies addressed in the same course, together with the previous and subsequent ones, in order to articulate them.

3. Activities, competencies, and evaluations of all the workshops were brought together.

4. The general rubric system was laid out for the project activity of each of the workshops, keeping in mind the analysed factors and respecting the variety of tasks that could be combined to reach the expected competencies. Descriptions of performances for each criterion and level were created.

\subsection{Results}

A generic analytical rubric was designed, where each competency is related to the proposed activities, and each criterion is assessed independently. Although assessing each one of the 
aspects can be slower than with a holistic rubric, this type of rubric allows gathering more information (indicative/diagnostic) for the professor and more instructional information for the student.

These evaluation rubrics are divided into four levels of achievement, which we think will help students better understand what is expected of them in each workshop and through each stage of the learning process. Generally speaking, each one of the workshops approaches its subject matter independently, bearing in mind the aspects that are described below and, finally, they are recorded as outcomes in the implementation of the main project for each of them.

In Workshop I, the student has basic general knowledge, technical (common to all the engineering degrees) as well as humanistic (specific to the degree). It can be said that they have completed their general instruction and are ready to start applying the set of skills they have acquired to projects at a basic level. In the third or fourth semester (depending on the university ETSID-EPSA), students are presented with the more specific common knowledge that they can apply in an introductory approach of the project.

Workshop II takes place in the $5^{\text {th }}$ and $6^{\text {th }}$ semesters. They complete the common instruction and this set of skills is applied to projects of a more demanding level. At the same time, the students also take blocks of elective subjects that allow them to develop specializations in different areas that support their project ability. They are in a position to consider the whole picture and look into the detail, applying themselves to more demanding projects. In addition, they have taken the courses in design representation, drawing and sketching, and computeraided design software application and they can go further.

Lastly, in Workshop III in the 7th - 8th semester, students have multiple instrumental and conceptual aids at their disposal with which they can develop detailed concepts and solutions, contemplating every aspect involved in the product, both previous ones and those derived from the project itself. The students are now prepared to develop the Final Project for their degree.

The rubrics developed follow a grid-type structure which has on the top axis the values divided into four levels of achievement. This helps students understand what is expected of them through each stage of the process. The site axis includes the competences and assessment criteria for them. The rubric describes the student's performance for each level described.

The rubrics give structure to observations and, instead of merely judging the student's performance, it describes the performance so it can be used for feedback in teaching (Mervat and Hanan, 2015). 
Table 1. Rubric Design Workshop I Font: own elaboration (2018)

\section{Bachelor in Industrial Design Engineering and Product Development WORKSHOP I}

INTRODUCTION TO DESIGN PROJECT AND PRACTICE DEVELOPMENT OF MODELS, MATERIALS AND BASIC DEFINITION PROCESSES ANALYSIS AND ARGUMENTATION OF PROPOSALS

\begin{tabular}{|c|c|c|c|c|}
\hline SKILLS/RESULTS & 4.- EXCELLENT & 3.- VERY GOOD & 2.- GOOD & 1.- UNSATISFACTORY \\
\hline $\begin{array}{l}21 \text { (G) ABILITY TO IDENTIFY, FORMULATE AND } \\
\text { SOLVE BASIC ENGINEERING OR ARCHITECTURE } \\
\text { PROBLEMS. } \\
\text { Observation, analysis of objects, and constructive } \\
\text { and material solutions. Laying out the problem }\end{array}$ & $\begin{array}{l}\text { Researches the targeted } \\
\text { subject thoroughly in all its } \\
\text { aspects, form, function, } \\
\text { material, constructive } \\
\text { solutions, etc. } \\
\text { Contributes own criticism to } \\
\text { the analysis and determines } \\
\text { with good arguments the }\end{array}$ & $\begin{array}{l}\text { Researches targeted subject, } \\
\text { form, function, material, } \\
\text { constructive solutions, etc. } \\
\text { Contributes own criticism to } \\
\text { the analysis and determines } \\
\text { with good arguments the } \\
\text { product to be developed. }\end{array}$ & $\begin{array}{l}\text { Researches the } \\
\text { targeted subject by } \\
\text { collecting information } \\
\text { without processing it } \\
\text { or drawing } \\
\text { conclusions. } \\
\text { Specifies the product } \\
\text { to be developed }\end{array}$ & $\begin{array}{l}\text { Collects very little data } \\
\text { without analysing it. }\end{array}$ \\
\hline $\begin{array}{l}7 \text { (G) CREATIVE ABILITY AND DEVELOPMENT OF } \\
\text { IMAGINATION IN THE AREAS OF ENGINEERING } \\
\text { AND ARCHITECTURE. Handling creative } \\
\text { techniques that improve conceptualising and } \\
\text { solving specific and general problems. } \\
\text { Formulating alternatives and improvements, } \\
\text { initiative regarding materials and shapes, etc. }\end{array}$ & $\begin{array}{l}\text { Searches thoroughly for the } \\
\text { solution, with multiple } \\
\text { alternatives. Makes } \\
\text { variations on the proposals } \\
\text { and on the definition of the } \\
\text { chosen product. }\end{array}$ & $\begin{array}{l}\text { Searches thoroughly for the } \\
\text { solution, with some } \\
\text { variations on the } \\
\text { alternatives. Looks in depth } \\
\text { into the chosen proposal. }\end{array}$ & $\begin{array}{l}\text { Proposes very few } \\
\text { alternatives and } \\
\text { variations on them. } \\
\text { Develops the proposal } \\
\text { assessing few aspects }\end{array}$ & $\begin{array}{l}\text { Develops a proposal } \\
\text { without suggesting } \\
\text { enough alternatives or } \\
\text { assessing the } \\
\text { different aspects. }\end{array}$ \\
\hline $\begin{array}{l}20 \text { (G) ABILITY TO USE THE NECESSARY TOOLS } \\
\text { AND INSTRUMENTS TO PROPERLY OBSERVE THE } \\
\text { SYSTEMS TARGETED BY THE STUDY. } \\
\text { Experimenting with materials and handling basic } \\
\text { workshop tools. Making and improving models of } \\
\text { the study subject. }\end{array}$ & $\begin{array}{l}\text { Experiments thoroughly with } \\
\text { the most appropriate } \\
\text { techniques, makes sketches, } \\
\text { scale models and work } \\
\text { models. Reworks proposals } \\
\text { to improve on the models. } \\
\text { Shows organisation in the } \\
\text { work process. Accuracy in the }\end{array}$ & $\begin{array}{l}\text { Experiments with the most } \\
\text { appropriate techniques, } \\
\text { makes sketches, scale } \\
\text { models and work models, } \\
\text { Shows some organisation in } \\
\text { the work process. Good } \\
\text { finishes, unions and aspects } \\
\text { related to scale. }\end{array}$ & $\begin{array}{l}\text { Experiments very little } \\
\text { with sketches, scale } \\
\text { models and work } \\
\text { models. Low accuracy } \\
\text { and carelessness in } \\
\text { the resolution of the } \\
\text { models. }\end{array}$ & $\begin{array}{l}\text { Presents poorly } \\
\text { approached and/or } \\
\text { resolved models. }\end{array}$ \\
\hline $\begin{array}{l}14 \text { (G) ABILITY TO COMMUNICATE USING } \\
\text { FORMAL, GRAPHIC AND SYMBOLIC LANGUAGES. } \\
\text { Making prior analyses of products and processes; } \\
\text { developing project presentations that show } \\
\text { proficiency in 2-D and 3-D advanced formal } \\
\text { visualization techniques. }\end{array}$ & $\begin{array}{l}\text { Organises and } \\
\text { communicates clearly, } \\
\text { concisely and thoroughly the } \\
\text { ideas/alternatives, as well } \\
\text { as the work processes } \\
\text { through language and visual } \\
\text { documentation (sketches, }\end{array}$ & $\begin{array}{l}\text { Organises and } \\
\text { communicates the } \\
\text { ideas/alternatives, as well } \\
\text { as the work processes } \\
\text { through language and visual } \\
\text { documentation (sketches, } \\
\text { hand renderings and }\end{array}$ & $\begin{array}{l}\text { Poor organisation and } \\
\text { communication of } \\
\text { ideas/alternatives } \\
\text { and of work processes } \\
\text { through language and } \\
\text { visual documentation. }\end{array}$ & $\begin{array}{l}\text { Hardly organises the } \\
\text { information. Does not } \\
\text { communicate the } \\
\text { ideas. }\end{array}$ \\
\hline $\begin{array}{l}25 \text { (G) ABILITY TO PREPARE, MANAGE AND } \\
\text { EXECUTE PROJECTS THAT MEET THE AESTHETIC, } \\
\text { TECHNICAL AND SAFETY REQUIREMENTS. } \\
\text { Demonstrating knowledge and handling of } \\
\text { techniques to manage and execute projects that } \\
\text { meet aesthetic, technical and safety } \\
\text { requirements.Making a first general approach to } \\
\text { defining the design project. }\end{array}$ & $\begin{array}{l}\text { Defines the project taking } \\
\text { into account all analysed } \\
\text { information and establishes } \\
\text { consistent functional, } \\
\text { ergonomic and formal } \\
\text { criteria for the product. }\end{array}$ & $\begin{array}{l}\text { Defines the project taking } \\
\text { into account the analysed } \\
\text { information and establishes } \\
\text { consistent functional, } \\
\text { ergonomic and formal } \\
\text { criteria for the product. }\end{array}$ & $\begin{array}{l}\text { Partially defines the } \\
\text { project taking into } \\
\text { account some aspects } \\
\text { of the information } \\
\text { analysed. Does not } \\
\text { suggest criteria for all } \\
\text { aspects of the product. }\end{array}$ & $\begin{array}{l}\text { Does not define the } \\
\text { project properly. Does } \\
\text { not take into account } \\
\text { important aspects and } \\
\text { does not suggest } \\
\text { criteria for the } \\
\text { product's design. }\end{array}$ \\
\hline $\begin{array}{l}6 \text { (G) ABILITY TO ASSESS, OPTIMISE AND } \\
\text { COMPARE DECISION-MAKING CRITERIA. } \\
\text { Demonstrating knowledge of techniques for } \\
\text { assessing, optimising and comparing decision- } \\
\text { making criteria for industrial design project } \\
\text { analysis, conceptualisation and development. }\end{array}$ & $\begin{array}{l}\text { Assesses consistently the } \\
\text { variety of alternatives } \\
\text { proposed. Arrives at } \\
\text { conclusions, proposes } \\
\text { improvements and applies } \\
\text { them in the development of } \\
\text { the final solution. } \\
\text { Develops criteria to assess }\end{array}$ & $\begin{array}{l}\text { Assesses the alternatives } \\
\text { proposed. Arrives at } \\
\text { conclusions, proposes } \\
\text { improvements and applies } \\
\text { them in the development of } \\
\text { the final solution. } \\
\text { Develops criteria to assess } \\
\text { conceptual proposals. }\end{array}$ & $\begin{array}{l}\text { Chooses the } \\
\text { alternative using } \\
\text { superficial arguments. } \\
\text { Proposes some } \\
\text { improvements and } \\
\text { applies them in the } \\
\text { development of the } \\
\text { final solution. }\end{array}$ & $\begin{array}{l}\text { Chooses the } \\
\text { alternative without } \\
\text { offering arguments } \\
\text { and does not propose } \\
\text { enough improvements } \\
\text { for its development. }\end{array}$ \\
\hline
\end{tabular}


Rubrics as a tool to coordinate assessment and progress in different design workshops of the degree in Industrial Design Engineering and Product Development

\section{Conclusions and further work}

This experience with other design educators has allowed us to understand and share the purpose and value of rubrics in guiding student work in design education. Also, it has highlighted the need to assess and share standards and criteria of quality.

The work of defining these rubrics has forced us to spell out what we are teaching and set some standards to compare the results. The participants agree on the need for qualitative standards and terms to obtain marks/scores and that these tools reveal considerably more about what students know and can do. Whether these rubrics are good or not will depend on how they are used and so, we expect to get more results in the following year.

The next step will be to include examples corresponding to the rubrics with precise explanations of every item for the different design workshops to better communicate among students and educators. Following Goodrich's recommendations (Goodrich, 2010), we may also listen to the students' critique assessments with these rubrics comparing them with real work to see how good the evaluations really are.

\section{Acknowledgments}

The work reported here has been a part of the educational innovation project "Integración y coordinación de la materia Taller de diseño como fundamento de la adquisición de competencias en el Grado de Ingeniería en Diseño Industrial y Desarrollo de Productos de la UPV" (project B06), supported by the Vicerectorat de Estudis Qualitat i Acreditació at the Universitat Politècnica de València.

\section{References}

Biggs, J. (2003). Teaching for quality learning at University: What the student does. Buckingham: Open University Press.

Bin Yang, N. (2010). Applying project-based learning to product design teaching. Engineering Design and Manufacturing Informatization, 171-173. pp 171.

Conchado, A. (2011). Modelización multivariante de los procesos de enseñanza aprendizaje basados en competencias en educación superior TESIS DOCTORAL, UNIVERSIDAD POLITĖCNICA DE VALĖNCIA Departamento de Estadística e Investigación Operativa Aplicadas y Calidad, Valencia, 65-67. 
Cooper, B. S., \& Gargan, A. (2009). Rubrics in Education Old Term, New Meanings. Phi Delta Kappan, 91(1), 54-55.

De Miguel et al., (2005). M., Alfaro, I., Apodaca, P., Arias, J. M., García, E., Lobato, C. y Pérez, A. (2005). Modalidades de enseñanza centradas en el desarrollo de competencias. Orientaciones para promover el cambio metodológico en el Espacio Europeo de Educación Superior. Dirección General de Universidades. Ministerio de Educación y Ciencia, Madrid.

Gerritsen, R. (1999). Do students study more thoroughly within a problem-based learning environments course. In J. Hommes (Ed.) Educational innovation in Economics and Business IV: Learning in a changing environment (pp.127-141). Dordrecth / Boston / London: Kluwer Academic Publishers.

Goodrich Andrade, H. (2000). Using rubrics to promote thinking and learning. Educational Leadership 57 (5), 13-18.

Goodrich Andrade, H. (2013). Teaching with Rubrics: The Good, the Bad, and the Ugly. College Teaching, Taylor and Francis, 53(1), 27-30.

Luft, J. A. (1999). Rubrics: Design and Use in Science Teacher Education. Journal of Science Teacher Education, 10(2), 107-121.

Mervat, A.; Hanan, E-D. (2015). Developing Assessment Rubric in graphic Design Studio-Based learning: Experiments in Active Teaching in a Case Study. International Design Journal, Vol 5, Issue 3, pp 1245-1255.

Reddy, Y. M., \& Andrade, H. (2010). A review of rubric use in higher education. Assessment \& Evaluation in Higher Education, 35(4), 435-448.

Rodrigo, A., Puyuelo M. y Merino, L. (2017). "La competencia transversal "pensamiento crítico" en la asignatura de Diseño y Accesibilidad". 25 Congreso Universitario de Innovación Educativa en las Enseñanzas Técnicas (CUIEET 2017), Badajoz, pp 681-690.

Schön, D. (1987). Educating the reflective practitioner: towards a new design for teaching and learning in the professions. San Francisco: Jossey.

Villardón, L. (2006). Evaluación del aprendizaje para promover el desarrollo de competencias. Educatio S.XXI, 24. pp 57-76. 